\title{
UTILIZATION OF CAROTENOID PIGMENTS EXTRACTED FROM TOMATO PEEL AS NATURAL ANTIOXIDANTS AND COLORANTS IN SUNFLOWER OIL AND SPAGHETTI
}

\author{
RIZK, E. M., S. H. BEDIER and MANAL A. EL_GENDY
}

Food Tech. Res. Ins., Agric. Res. Center, Giza, Egypt.

(Manuscript received 5 December 2013)

\begin{abstract}
Extraction and Determination of carotenoids pigment from tomato peel was optimized for identification of the major constituent of the extract by HPLC to be used as alternative natural colorants in some processed foods, i.e. spaghetti. Also the effect of using carotenoids from tomato peel as natural antioxidant on sunflower oil was also undertaken.

Tomato peel contained $720 \mathrm{mg}$ carotenoids $/ 100 \mathrm{~g}$. The carotenoids (lyco-red) extracted from tomato peel were separated based on their functional groups into thirteen fractions and identified nine compounds from them by HPLC. lycopene was the major carotenoid represented with $86.12 \%$ of total carotenoids from tomatoes peel followed by $3.15 \%$ phytoene, $2.31 \%$ phytofluene, $2.11 \% \quad \beta$-carotene, $1.71 \%$ cis-lycopene, $1.51 \%$ lutein, $0.61 \%$ cis- $\zeta$-carotene, $0.56 \% \quad \zeta$-carotene, and $0.52 \%$ y-carotene respectively. Antioxidant activity of carotenoids from tomato peel were evaluated by measuring Rancimat test on sunflower oil by adding 50 to $200 \mathrm{ppm}$ carotenoids from tomato peel and radical scavenging activity RSA by DPPH. The sunflower oil containing 50 to $200 \mathrm{ppm}$ carotenoids from tomato peel showed a higher induction period compared to the sunflower oil containing $200 \mathrm{ppm}$ (BHT) as a synthetic antioxidants.

Optimum cooking time, cooking weight and swelling index were not differed within each level of oil carotenoids tomato peel powder compared with control. On the other hand, spaghetti cooking losses were decreased by increasing the level of carotenoids in spaghetti compared with control (without added carotenoids). Supplementing spaghetti with carotenoid (lyco-red) from tomato peel increased the Radical Scavenging activity (RSA) in the spaghetti by increasing the percentage of added carotenoid (lyco-red) from tomato peel. Sensory evaluation of spaghetti prepared from carotenoid pigments from tomato peel revealed the highest score of color, taste, texture and overall acceptability compared with control and other tested samples.
\end{abstract}

Key words: - Natural colorants, Antioxidants, Radical Scavenging Activity (RSA), Carotenoids, Tomato peel, Lycopene, Spaghetti. 


\section{INTRODUCTION}

Natural colored pigments from plant products have drawn a great attention in all worldwide. These pigments display various colors and are made up of different phytochemicals commonly found in the food matrix such as orange ( $\beta$-carotene), yellowish-green (lutein), green (chlorophyll), and blue-purple (anthocyanin) (Mortensen, 2006). Lycopene is the red colored pigment abundantly found in red colored fruits and vegetables such as tomato, papaya, pink grapefruit, pink guava and watermelon. Lycopene is a carotenoid hydrocarbon (also called carotene). The extended conjugated double bond system of these compounds is an important feature in the carotenoids responsible for their attractive colors because it forms the light absorbing chromophore (Rodriguez and Kimura, 2004).

The existence of visible color in these compounds requires at least seven conjugated double bonds. The greater the number of conjugated double bonds, the higher a wavelength value for maximum absorption (Rodriguez, 2001). Observed lycopene is one of the popular pigments highly accepted by food industry as a food additive and also for its health benefits (Rao and Rao- 2007).

The importance of natural food additives is given more attention due to their extensive use of the natural ingredients rather than synthetic compounds in food, cosmetics and pharmaceuticals. Meanwhile, the prices of raw materials are increasing and their availability is decreasing. (Amin, \& Mukhrizah, 2006).

The protective effects of lycopene have been shown on oxidative stress, cardiovascular disease, hypertension, atherosclerosis, cancers, diabetes and others. However, there are still no conclusive results reported due to the fact studies on the role of lycopene against these diseases is still on going. Oxidative stress is one of the major risk factors of chronic diseases (Rao and Rao 2007). Free radicals or oxidants are potential contributors leading to oxidative stress. In vitro, ex vivo, and in vivo studies have been carried out to demonstrate the effects of lycopene against oxidative stress. In this context, lipid, protein and DNA oxidation are closely related to oxidative stress.

Lycopene is the red pigment that plays an important role in plant and animals. In human health, much evidence shows that consumption of lycopene rich foods can help in preventing degenerative diseases, but very limited studies have found a beneficial role of the consumption of lycopene alone. The interaction of lycopene with other active compounds is crucial for obtaining its optimal function in human health.

The peel fraction of tomato waste contains lycopene up to five times more than the pulp (on wet basis), but its high moisture levels and susceptibility to microbial spoilage make the storage and processing of this material quite problematic (Kaur et.al. 2008). 
Lycopenes major commercial use is as a coloring agent in the feed, food, nutraceuticals and pharmaceutical industries, although its biological properties, as anti-oxidant and anti-carcinogenic agent, have been gaining increased attention in the last decade (Stahl and Sies, 2005). Due to this fact, lycopene consumption is strongly recommended for reducing the risk of atherosclerosis, coronary heart diseases and some types of cancer [Shi and Maguer, 2000].

Lycopene, a member of carotenoid family, is a lipid soluble antioxidant synthesized by many plants and microorganisms but not by animals and humans (Kaur etal.,2008) where it serves as an accessory light-gathering pigment and protects them against the toxic effects of oxygen and light. It is a red pigment without pro vitamin A activity that imparts color to many fruits and vegetables.

The objective of this study was to extract and identification of carotenoids extracted from tomato peel and utilization as natural antioxidants colorants and of some processed foods such as sunflower oil and spaghetti (with level of 1.0, 2.0, 3.0, 4.0 and $5.0 \%$ ).

\section{MATERIALS AND METHODS}

\section{Material}

Tomato peel was obtained from Kaha Company for Preservative Foods Kaha, Kalyobia, Egypt.

The solvents used for spectral and HPLC analysis were of HPLC grade and all other solvents used in this study were of ACS grade and obtained from Sigma Chemical Company, St. Leuis,USA.

Refined sunflower free from antioxidants was obtained from Arma Food Industries, $10^{\text {th }}$ of Ramadan Cairo, Egypt.

Wheat flour (72\%ext.) milled from Hard Red Winter wheat (HRW) obtained from Ebn EL-Khatab Mills Company $\underline{6}$ th October City.

Synthetic antioxidant, namely butylated hydroxy toluene (BHT) and standard carotenoid were purchased from Sigma Chemical Co., St Lewis, USA.

\section{Methods}

\section{Extraction of carotenoid from tomato peels powder:-}

Carotenoids were extracted according to the method described by Hackett, et.al, 2004. Obtained tomato peel was dried in oven dryer at 40C until the moisture content reached to $6 \%$ then ground and passed through $0.15 \mathrm{~mm}$ sieves. Hundred grams of tomato peel powder were placed in 4-L beaker and $500 \mathrm{~mL}$ of ethanol was added, stirred for $20 \mathrm{~min}$, and allowed to stabilize for $1.5 \mathrm{~min}$. The mixture was then homogenized for $1 \mathrm{~min}$. After that the mixture was filtered through Whatman filter papers (Whatman No 1 and cheesecloth. The filtrate was mixed with $250 \mathrm{~mL}$ of acetone/hexane solution (50:50, v/v) and homogenized for $1 \mathrm{~min}$. A separatory funnel 
was used to separate the non polar hexane layer containing lipid materials from the water-soluble fraction, and solvents were removed by reduced pressure at $40{ }^{\circ} \mathrm{C}$. The oily of carotenoids extracted from tomato peel was kept in a dark bottle and kept under freezing temperature until analysis and utilization.

\section{Determination of total carotenoids:-}

Carotenoid content was determined by spectophotometric method according to (Hornero and Munguez 2001). Carotenoid extracted from tomato peel was dissolved in hexane and the absorbance was measured using a spectrophotometer at 472 and $508 \mathrm{~nm}$.

\section{Determination of lycopene :-}

Lycopene was estimated according to the method described by (AOAC, 2007).

\section{Identification of the carotenoids:-}

The carotenoids (lyco-red) extracted from tomato peel were identified by Knauer HPLC pump 64 according to the method reported by (Gaylek et al., 1987) using octadecyl silane C 18, $3.9 \times 150 \mathrm{~mm}$. For both HPLC columns, two solvents were used for elution: (1) methanol (2) ethyl acetate.

The flow rate was $1.8 \mathrm{ml} / \mathrm{min}$ and absorbance was measured at $475 \mathrm{~nm}$.

A mixture of methanol and ethyl acetate $(54: 46)$ as mobile phase,(sample amount:20ul, flow, $1.8 \mathrm{~mL} / \mathrm{min}$ ) and detected at $475 \mathrm{~nm}$.

\section{Evaluation of antioxidant activity:-}

Carotenoid extracted from tomato peel was tested as antioxidant by using the Rancimat method 50,100,150, and $200 \mathrm{ppm}$ of the carotenoids extracted from tomato peel were mixed with $25 \mathrm{~g}$ of sunflower oil in a flask, against a sample $25 \mathrm{~g}$ of sunflower oil mixed with 200 ppm of synthetic BHT in a flask. On the other hand, the control was sunflower oil without any additives. The method was described by (Mubarak,2003).

\section{Chemical and Physical properties of $\mathbf{7 2} \%$ ext. wheat flour:-}

Moisture, crude protein, crude fat, ash, fiber, minerals, and falling number were determined according to the procedure described in the AOAC (2007). Total carbohydrate was calculated by the difference.

\section{Preparation of spaghetti :-}

Spaghetti samples were prepared from wheat flour $72 \%$ ext., water $35 \%$ and salt $1 \%$. Each sample was blended with different level of carotenoid from tomato peel $(1.0,2.0,3.0,4.0$ and $5.0 \%$ as wheat flour weight). The mixture of ingredients was placed in a mixing bowl (Kitchen Aid Mixer) and mixed at speed 1 for 1 min., water was added and mixing was continued at speed 1 for 2 min., followed by mixing at speed 2 until the dough stiffened. The dough was rounded (shape to ball). Covered with plastic wrap, allowed to rest about $30 \mathrm{~min}$., hand kneaded for about $1 \mathrm{~min}$ and sheeted with wooden rolling pin to about $1.5 \mathrm{~cm}$. thickness. The sheet of dough was 
passed through a hand-operated pasta machine (Ampia, Tipo Lusso, Model 150, Italy). Spaghetti was cut into strips $5 \mathrm{~mm}$ wide, hung on rod, hardened on air dried for $24 \mathrm{~h}$ at $25 \mathrm{C} \pm 2 \mathrm{C}$. The spaghetti was dried to $6.40 \%$ moisture in aerated oven at $70 \mathrm{C}$ for $24 \mathrm{~h}$, cooled at room temperature and the produced spaghetti was packed in polyethylene bag until tested.

Cooking qualities of spaghetti under investigation namely optimum cooking time, spaghetti cooking weight, cooking loss and swelling index were measured by the method of (Dexter et al 1983).

\section{Antioxidant Capacity:-}

A-Radical Scavenging Activity (RSA \%) assay Free radical Scavenging Activity (RSA) of the samples was measured using the method of Brand-Williams et al (1995) and expressed as percentage inhibition of the DPPH radical and was determined by the following equation:

RSA $\%=$ Abs (sample) - Abs (control) $\times 100 /$ Abs (control).

\section{Sensory evaluation:-}

Sensory evaluation was carried out by ten panelists at Food Tech. Research Institute (FTRI). The panelists were asked to evaluate color, taste, texture and overall acceptability for cooked prepared spaghetti according to the method described by (Dexter et al 1983).

\section{Statistical analysis:-}

Means of data obtained for sensory evaluation of samples were evaluated using Duncan's multiple range test to identify significant differences at the 0.05 probability $(\mathrm{p} \leq 0.05)$ using the statistical analysis system "SAS" (SAS Institute Inc., 1999).

\section{RESULTS AND DISCUSSION}

\section{Chemical composition of tomato peel:-}

Gross chemical composition of tomato peel was determined and the data were recorded in Table 1. The results showed that, the tomato peel contain (on dry weight basis) $10.12 \%$ crude protein, $4.33 \%$ ash, $2.60 \%$ ether extract, $53.74 \%$ crude fibre and $29.21 \%$ total carbohydrate. On the other hand, the total carotenoid, total polyphenol and lycopene in tomato peel were $720 \mathrm{mg} / 100 \mathrm{~g}, 240.62 \mathrm{mg} / 100 \mathrm{~g}$ and 615 $\mathrm{mg} / 100 \mathrm{~g}$ dry weight respectively. These results are in agreement with (Rodriguez, et.al, 2004), stated that, the amount of carotenoid from tomato peels ranged from 520 to $950 \mathrm{mg} / 100 \mathrm{~g}$. Aghel et.al,(2011) found that the lycopene is the major sources of carotenoid in tomato peel and this pigment represented more than $85 \%$ of all carotenoid, its concentration can vary from 30 to $200 \mathrm{mg}$ in the fresh products or from 430 to $2000 \mathrm{mg} / 100 \mathrm{~g}$ dry weight basis. 
Table 1. Chemical composition of tomato pee**

\begin{tabular}{|c|c|}
\hline Components & $\begin{array}{c}\text { Tomato peel } \\
\text { powder }\end{array}$ \\
\hline Crude protein \% & 10.12 \\
\hline Ash \% $\%$ & 4.33 \\
\hline Ether extract \% & 2.60 \\
\hline Crude fiber \% & 53.74 \\
\hline Total carbohydrates \% & 29.21 \\
\hline$* *$ Total carotenoid & 720.0 \\
\hline$* *$ Phenolic content & 240.62 \\
\hline$* *$ Lycopene & 615.0 \\
\hline
\end{tabular}

*on* dry basis.

$* * \mathrm{mg} / 100 \mathrm{~g}$.

\section{Chemical and Physical composition of $\mathbf{7 2} \%$ ext. wheat flour:-}

Wheat flour with $72 \%$ ext. was analyzed for moisture, protein, fiber. Ash, fat, carbohydrates, minerals, falling number, and liquefaction number. The obtained results are shown in Table (2). The results indicated that moisture, protein, fiber, ash, fat, and carbohydrates of $72 \%$ ext. were: $11.77,12.87,0.98,0.522,0.42$ and $85.21 \%$ respectively. These data are in the same line with that obtained by Farvilli, et al., (1997). In same table, the mineral content of $72 \%$ ext. wheat flour was: 215.121 , $130.663,3.577,16.443,5.113,88.449,223.132$, and 3.633 ( $m g 100 \mathrm{~g} /$ flour) for $\mathrm{Mg}$, $\mathrm{Na}, \mathrm{Zn}, \mathrm{Mn}, \mathrm{Fe}, \mathrm{Ca}, \mathrm{K}$, and $\mathrm{Cu}$, respectively. The obvious results were in agreement with those obtained by Bedeir (2004) in minerals contents of $\mathrm{Na}, \mathrm{Zn}, \mathrm{Mn}, \mathrm{Fe}, \mathrm{Ca}$, and $\mathrm{Cu}$, but higher in $\mathrm{K}$ content and lower in $\mathrm{Mg}$ content. Also, falling number was 298 second. While, liquefaction number was (24.1). These results are agreement with that obtained by Farvilli, et al., (1997).

Table 2. Chemical and Physical composition of. wheat flour(72\% ext).

\begin{tabular}{|c|c|}
\hline Components & $72 \%$ ext. wheat flour \\
\hline Crude protein \% & 12.87 \\
\hline Crude fiber \% & 0.98 \\
\hline Ash \% & 0.522 \\
\hline Fat \% & 0.42 \\
\hline$*$ Motal carbohydrates \% & 85.21 \\
\hline$* * \mathrm{Na}$ & 215.121 \\
\hline$* * \mathrm{Zn}$ & 130.663 \\
\hline$* * \mathrm{Mn}$ & 3.577 \\
\hline$* * \mathrm{Fe}$ & 16.443 \\
\hline$* * \mathrm{Ca}$ & 5.113 \\
\hline$* * \mathrm{~K}$ & 88.449 \\
\hline$* * \mathrm{Cu}$ & 223.132 \\
\hline Falling number (sec) & 3.633 \\
\hline Liquefaction number & 298 \\
\hline By & 24.1 \\
\hline
\end{tabular}

*By differences

**mg $100 / g$ flour. 


\section{Identification of carotenoids extracted from tomato peel:-}

Identification of carotenoids extracted from tomato peel was done by HPLC are shown in Table (3) and fig. (1), the carotenoids extracted from tomato peel were separated based on their functional groups into thirteen fractions and identified nine compounds from them by HPLC. The carotenoids extracted from tomato peel


carotene, 6) $\zeta$-carotene, 7) $\beta$-carotene, 8) phytofluene, and 9) phytoene respectively. The obtained results indicated that, the lycopene was the major carotenoids which represented with $86.13 \%$ of total carotenoids from tomatoes followed by $3.15 \%$ phytoene, $2.31 \%$ phytofluene, $2.11 \% \beta$-carotene, $1.71 \%$ cis-lycopene, $1.51 \%$ lutein, $0.61 \%$ cis- $\zeta$-carotene, $56 \% \zeta$-carotene, and $52 \%$ Y-carotene respectively. These results are agreement with (Aghel et.al. 2011).

Results also indicated that the lycopene was the predominated pigment in tomato peel, followed by phytoene, phytofluene, $\beta$-carotene and cis- lycopene respectively, while minor amounts of 9-cis-lutein, 13 -cis- $\beta$-carotene and 9-cis- $\beta$-carotene were also detected.

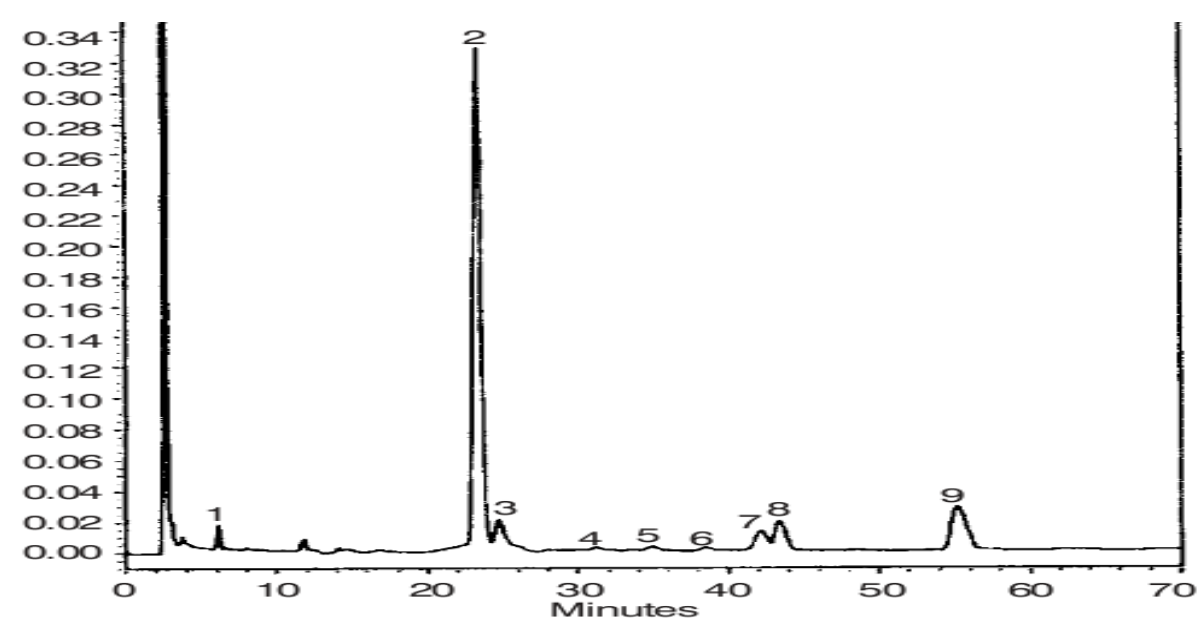

Fig.1. HPLC separation of carotenoids extracted from tomato peel.

Table 3. Identification of carotenoids extracted from tomato peel.

\begin{tabular}{|c|c|c|c|}
\hline Peak & RetentionTime & Area \% & Identified of carotenoid \\
\hline 1 & 5.86 & 1.50 & Lutein \\
\hline 2 & 22.21 & 86.13 & Lycopene \\
\hline 3 & 25.15 & 1.71 & cis-lycopene \\
\hline 4 & 31.64 & 0.52 & Y-carotene \\
\hline 5 & 35.80 & 0.61 & cis-ל-carotene \\
\hline 6 & 39.11 & 0.56 & $\zeta$-carotene \\
\hline 7 & 41.90 & 2.11 & $\beta$-carotene \\
\hline 8 & 43.86 & 2.31 & Phytofluene \\
\hline 9 & 54.85 & 3.15 & Phytoene \\
\hline
\end{tabular}




\section{Antioxidant activity of carotenoids extracted from tomato peel:-}

Antioxidants are usually added to fats, oils and foods containing fats in order to inhibit the development of off-flavor arising from oxidation of unsaturated fatty acid.However, the use of commercial synthetic antioxidants is strictly controlled and increasing. Consumer awareness of food additives and safety has promoted increased interest to the use of natural antioxidants e.g., carotenoid, ascorbic acid and tocopherol (Brand - Williams, etal.1995).

Table (4) shows the induction period of sunflower oil containing different concentrations of carotenoids extracted from tomato peel as natural antioxidant by the Rancimat test at $110^{\circ} \mathrm{C}$. Results indicated that, induction period of sunflower oil was increased by increasing the additional of carotenoids from tomato peel. The induction period was 3.25 and $7.20 \mathrm{~h}$ for sunflower oils without adding antioxidant and that contained 200 ppm BHT, respectively, meanwhile, our results showed that the induction period was increased gradually by adding and increasing the concentration of carotenoids extracted from tomato peel as natural antioxidants. These values of induction periods increased to $9.40,12.30,16.22$ and $20.70 \mathrm{~h}$ for sunflower oil that contained 50,100,150 and 200 ppm of carotenoids extracted from tomato peel, respectively. These results are similar to those given by (Nilson et al,1999) who proved that, the carotenoids acts as antioxidants by destroying the free radicals. Also (Mubarak, 2003 ) reported that, carotenoids lyco-red as natural antioxidant extracts of $0.1 \%$ concentration increased the induction period of sunflower oil assessed by Rancimat method. The replacement of synthetic antioxidant by lycored natural antioxidant may have benefits due to health implication of functional parameter such as stability in both oil and water. Lycopene, a C 40 poly isoprenoid compound containing 13 double bonds, is the most abundant carotenoid, accounting for approximately $80-90 \%$ of the total pigment contents in tomatoes. With its 11 conjugated and two non-conjugated double bonds, it was found to be a more efficient antioxidant (singlet oxygen quencher) than $\beta$-carotene, a -carotene, and a -tocopherol (Chun et.al, 2009). Lycopene as antioxidant has a single oxygen quenching ability twice as high that of $\beta$-carotene and 10 times higher than that $a-$ tocopherol.

Table 4. Relation between induction periods of sunflower oil containing different ratios of carotenoids as natural antioxidant.

\begin{tabular}{|c|c|}
\hline Sunflower treatments & Induction periods $(\mathrm{h})$ \\
\hline free from additives & $3.25 \mathrm{e}$ \\
\hline containing $200 \mathrm{ppm}$ BHT & $7.20 \mathrm{de}$ \\
\hline containing $50 \mathrm{ppm}$ carotenoids & $9.40 \mathrm{~d}$ \\
\hline containing $100 \mathrm{ppm}$ carotenoids & $12.30 \mathrm{c}$ \\
\hline containing $150 \mathrm{ppm}$ carotenoids & $16.22 \mathrm{~b}$ \\
\hline containing $200 \mathrm{ppm}$ carotenoids & $20.70 \mathrm{a}$ \\
\hline
\end{tabular}

Values with different letters in the same column are significant different at $\mathrm{P}<.0 .05$. 


\section{Cooking characteristics of spaghetti :-}

Cooking characteristics of spaghetti prepared with different ratio carotenoid from tomato peel are summarized in Table (5). Optimum used cooking time was 10 min, cooking weight of used $10 \mathrm{~g}$ dry matter of spaghetti $32 \mathrm{~g}$, Swelling Index value was 6.0. $32 \mathrm{gm}$. These values were not differed with each level of carotenoids pigment and control sample. These results are in agreement with Rizk, and Tolba (2010).

Spaghetti cooking losses in all samples prepared with adding different ratio of carotenoid (lyco-red) from tomato peel ranged from 3.0 to 7.40 . On the other hand, cooking loss for all investigated samples was lower than the control. In other words, as the level of carotenoid from tomato peel is higher in prepared spaghetti the lower is the cooking loss. For instance, cooking loss was7.40, 6.30, 5.40, 3.30 and $3.0 \%$ for spaghetti contained 1.0, 2.0, 3.0, 4.0 and $5.0 \%$ carotenoid from tomato peel respectively. The stability of decrement of weight loss may be due to the capability of carotenoid from tomato peel to be present in the form of complex with protein or lipoprotein. Their submicroscopic structure may also be a factor in the outstanding stability of carotenoid from tomato peel during manufacturing of spaghetti. (Dexter, etal.1983).

Table 5. Cooking characteristics of spaghetti prepared with different ratio of carotenoid from tomato peel

\begin{tabular}{|c|c|}
\hline$\%$ adding of pigment & $\begin{array}{c}\text { Dry matter loss at optimum cooking time of } \\
\text { spaghetti }\end{array}$ \\
\hline Control & $10.0 \mathrm{a}$ \\
\hline $1 \%$ Carotenoids & $7.40 \mathrm{~b}$ \\
\hline $2 \%$ Carotenoids & $6.30 \mathrm{c}$ \\
\hline $3 \%$ Carotenoids & $5.40 \mathrm{~d}$ \\
\hline $4 \%$ Carotenoids & $3.30 \mathrm{e}$ \\
\hline $5 \%$ Carotenoids & $3.00 \mathrm{e}$ \\
\hline
\end{tabular}

Value with different letters in the same column are significant at $\quad p<0.05$.

\section{Antioxidant Capacity :-}

Radical Scavenging Activity (RSA) of spaghetti prepared with different ratios of carotenoid from tomato peel during storage period is illustrated in Table (6). Revealed that, supplementing spaghetti with carotenoid from tomato peel increased the RSA in the spaghetti by increasing the percentage of added carotenoid from tomato peel. It was noticed that, RSA \% of control supplemented with $1 \%$ and $5 \%$ extract increased by $75.39 \%$ and $195.04 \%$ respectively compared with control at zero time, while the 
corresponding rates after 6 months of storage were $82.81 \%$ and $216.93 \%$ in the same order.

However, the percentage of RSA gradually decreased during storage period for all treatments.

Table 6. Radical Scavenging Activity (RSA) of spaghetti prepared with different ratios of carotenoid from tomato peel during storage period

\begin{tabular}{|c|c|c|c|c|c|c|}
\hline \multirow{2}{*}{ Storage periods } & \multirow{2}{*}{ Control } & \multicolumn{5}{|c|}{ Level of carotenoids } \\
\cline { 3 - 7 } & & $1 \%$ & $2 \%$ & $3 \%$ & $4 \%$ & $5 \%$ \\
\hline Zero time & 27.43 & 48.11 & 58.31 & 63.44 & 72.14 & 80.93 \\
\hline 1 month & 25.11 & 44.60 & 53.10 & 60.52 & 69.22 & 77.83 \\
\hline 2 month & 22.13 & 40.22 & 49.80 & 56.76 & 65.30 & $72.70^{c}$ \\
\hline 4 month & 20.90 & 37.15 & 43.19 & 52.40 & 62.52 & 67.50 \\
\hline 6 month & 19.20 & 35.10 & 38.22 & 47.15 & 58.44 & 60.85 \\
\hline
\end{tabular}

\section{Sensory parameters of spaghetti prepared with different ratio of carotenoids from tomato peel :-}

Means of the score given by the panelist for spaghetti manufactured with wheat flour $72 \%$ and treated with different ratio carotenoids from tomato peel compared with the control (without carotenoids pigment) were recorded with the results of statistical tests applied Table(7). There were a significant difference in color, taste, texture and overall acceptability criterion among different tested spaghetti either in the control or those prepared with adding lycopene pigments. While, there is no significant difference between spaghetti prepared with adding 3.0 and $4.0 \%$ carotenoids from tomato peel but there were significant differences between the samples and other tested spaghetti in all recorded sensory attributes. Meanwhile, spaghetti prepared with adding 3.0\% carotenoids pigment received the higher color, taste, texture and overall acceptability score followed by $4.0 \%, 5.0 \%, 2.0 \%$, and $1.0 \%$ and the control respectively. On the other hand, control spaghetti sample received the lower score in all sensory criterions. Results showed also, that the color criterion was highly correlated with the final product as both color and overall acceptability had the same letter of significance in all samples. Therefore, the best level carotenoids from tomato peel improved the sensory quality attributes of prepared spaghetti were $3.0 \%$ to $4.0 \%$ but less than $2.0 \%$ of carotenoids from tomato peel was less acceptable for eating spaghetti qualities. 
Table 7. Sensory parameters of spaghetti prepared with different ratio of carotenoids from tomato peel

\begin{tabular}{|c|c|c|c|c|}
\hline \multirow{2}{*}{ Treatments } & \multicolumn{4}{|c|}{ Quality attributes of spaghetti } \\
\cline { 2 - 5 } & Color & Taste & Texture & $\begin{array}{c}\text { Overall } \\
\text { acceptability }\end{array}$ \\
\hline *Control & $5.10 \mathrm{e}$ & $5.40 \mathrm{e}$ & $5.50 \mathrm{e}$ & $5.20 \mathrm{e}$ \\
\hline $1 \%$ Carotenoids & $6.00 \mathrm{~d}$ & $6.20 \mathrm{~d}$ & $6.40 \mathrm{~d}$ & $6.30 \mathrm{~d}$ \\
\hline $2 \%$ Carotenoids & $7.50 \mathrm{c}$ & $7.20 \mathrm{c}$ & $7.30 \mathrm{c}$ & $7.40 \mathrm{c}$ \\
\hline $3 \%$ Carotenoids & $9.40 \mathrm{a}$ & $9.30 \mathrm{a}$ & $9.50 \mathrm{a}$ & $9.50 \mathrm{a}$ \\
\hline $4 \%$ Carotenoids & $9.10 \mathrm{a}$ & $9.00 \mathrm{ab}$ & $9.00 \mathrm{ab}$ & $9.10 \mathrm{a}$ \\
\hline $5 \%$ Carotenoids & $8.40 \mathrm{~b}$ & $8.50 \mathrm{~b}$ & $8.30 \mathrm{~b}$ & $8.50 \mathrm{~b}$ \\
\hline
\end{tabular}

Value with different letters in the same column are significant at $p<0.05$

*Control without adding carotenoids pigment.

\section{REFERENCES}

1. Amin, I. and Mukhrizah, O. 2006. Antioxidant capacity of methanolic and water extracts prepared from food-processing by-products. J. Sci. Food Agric. 86, 778-784.

2. Aghel, N., Z, Ramezani,S. Amirfakhrian. 2011. Isolation and quantification of lycopene from tomato cultivated in Dezfoul, Iran journal or Natural Pharmaceutical Products, 6(1):9 - 15.

3. AOAC. 2007. Official of Analysis.(18 th Ed.) Chapter 33, pp.10,70 - 72, Chapter 45, pp101.Association of Official Analytical Chemists. Washington, D.C., USA.

4. Bedeir, S.H. 2004. Addition of gluten, pentosans, ascorbic acid, and milk casein to wheat flour to produce high quality bakery products. Ph.D.Thesis, Fac. of Agric. Banha Univ. Egypt.

5. Brand-Williams, W., Cuvelier, M. E. \& Berset, C. 1995. Use of free radical method to evaluate antioxidant activity. Lebensmittel-Wissens-chaft and Technology, 28, 25-30.

6. ChunYi, J. Shi, S. Xue, Y. Jiang and L. Dong. 2009. Effects of supercritical fluid extraction parameters on lycopene yield and antioxidant activity, Food Chemistry, 113, 4, 1 088-1 094,

7. Dexter, J. e., R.R. and Morhan,B.C. 1983. Spaghetti stickiness : some factors influencing stickiness and relation ship to other cooking quality characteristics J. Food Sci., 48: 1545 - 1553. 
8. Farvilli, N., Walker,C, and Qarooi, J. 1997. The effects of protein content flour and emulsifiers on tanoor bread quality. J, Cereal Sci. 26:137 - 142.

9. Gaylek, G., T.S. Chen, and T. Philip. 1987. Quantitative analysis of carotenoid and carotenoid ester in fruits by HPLC. Red bell peppers. J. Food Sci. 52: 10711075.

10. Hackett,M.M., J. H. Lee, D. Francis, and Schwartz, S.J. 2004. Thermal Stability and Isomerization of lycopene in Tomato Oleoresins from different varieties. Journal of Food Science, Vol., 69: 536 - 541.

11. Hornero, D. and Munguez, M.L. 2011. Rapid spectophotometric determination of red and yellow isochromic carotenoid fraction in paprika and red pepper olio resins, Journal of Agriculture and Food Chemistry, $49: 3584$ - 3588.

12. Kaur D, Wani AA, Oberoi DPS, Sogi DS. 2008. Effect of extraction conditions on lycopene extractions from tomato processing waste skin using response surface methodology. Food Chem. 108: 711-718.

13. Mortensen, A. Carotenoids and other pigments as natural colorants. Pure Appl. Chem. 2006, 78, 1477-1491.

14. Mubarak, A.E. 2003. Characteristics and identification of natural antioxidant extracts and role in the retarding of sunflower oil oxidation during deep fat frying of French fries potato. J. of Home Economics, Minufiya Univ, 13: 63-83.

15. Nilson, B.R., Mortensen, A. Jorgensen ,K and L.H. Skibsted. 1999. Singlet versus triplet reactivity in photo degradation of $\mathrm{C} 40$ carotenoid. J. Agric. Food Chem. 44: 2106-2113.

16. Rao, A.V., and Rao, L.G. 2007. Carotenoids and human health. Pharmacol. Res., 55, 207-216.

17. Rizk, E.M. and K.H. Tolba. 2002. Isolation and stabilization of carotenoids from sweet red pepper and utilization as food colorants. Arab Univ. J. Agric, Sci. Ain Shams Univ., Cairo, 10: 221-234.

18. Rodriguez,A, and Kimura, M. 2004. Carotenoids in foods.In Harvest plus Handbook for Carotenoid Analysis, IFPRI and CIAT: Washington, DC, USA, pp. 2-7.

19. Rodriguez,A. 2001. A Guide to Carotenoid Analysis in Foods, ILSI Press: Washington, D.C., USA, pp. 1-45.

20. SAS Institute Inc. 1999. Statistical Analysis System. User's Guide: Statistics,SAS, Institute Inc., Editors, Cary, NC.

21. Stahl, W., Sies, H. 2005. Bioactivity and protective effects of natural carotenoids. Biochim. Biophys. Acta, 1740, 101-107. 
الإستفاده من الصبغات الكاروتينيه المستخلصه من قشور الطماطم كماده مضاده للاكسده في زيت دوار الثمس ومادة ملونه طبيعية في المكرونه

عفت مهاى رزق ، صلاح حزه محمد ، منال عباس الجندى

$$
\text { معهُ بحوت تكنولوجيا الاغنيه - مركز البحوث الزراعية - الجيزة - مصر }
$$

- تم استخدام تقنيه الفصل الكروماتوجر افي تحت ضغط عالي HPLC في فصل وتقدير الصبغات

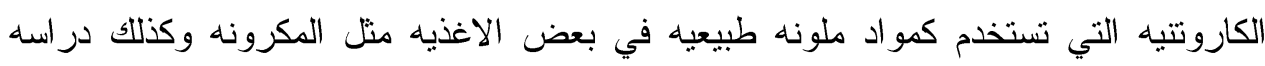

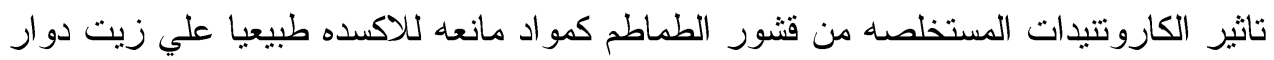

\section{الثمس .}

- تحتوي قتشور الطماطم علي • VY ملاجم من الكاروتتيدات/· · اجم ويعتمد استخلاص

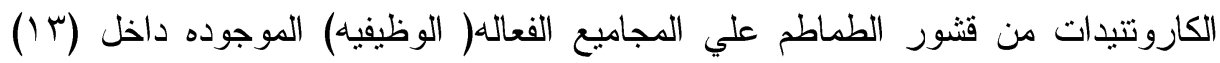
مركب تم فصلهم و التعرف علي عدد (9) مركبات منهم باستخدام الفصل الكروماتوجر افي

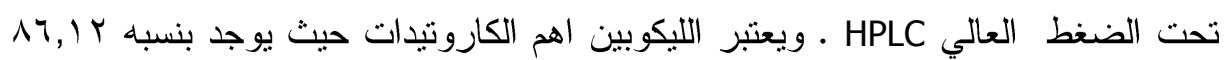

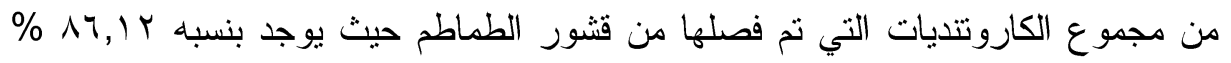

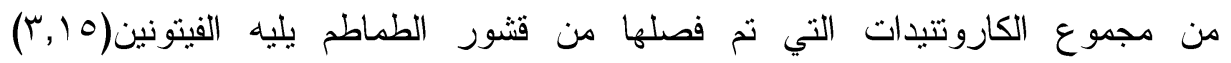

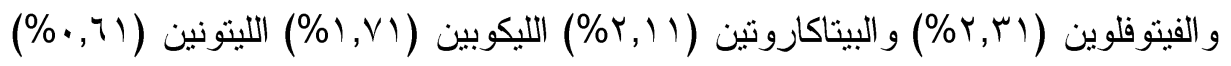

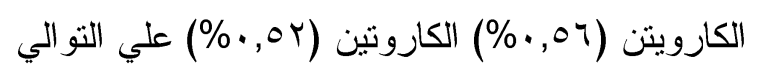
- تم تقدير كلا من زمن الطبخ المثالي - وزن المكرونه بعد الطبخ - معامل التمدد ( الزيادة فى الحجم والوزن نتيجة التشرب) لعينات المكرونه المطبوخه المضاف اليها الصبغات الكاروتتيدديه مقارنه بعينه المكرونه الكنترول ـ كذللك اظهرت النتائج تتاقص معددل الفقدات

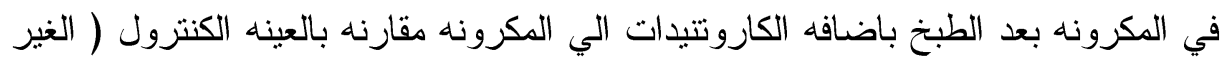

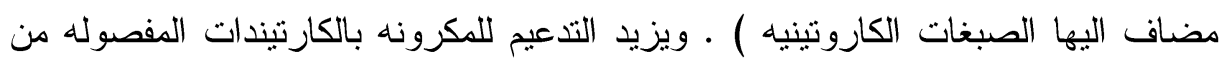
قشور الطماطم من معدل (RSA) وذللك بزياده نسبه الكاروتيندات المضافه لها . - اظهر التقييم الحسي للمكرونه المضافه اليها الصبغات الكاروتينديه المفصوله من قثشور الطماطم انها اعطت اعلي تقييم حسي بالنسبه لصفات اللون و الطعم و القو ام ومجموع الصفات الحسيه مقارنه بالعينه الكنترول و العينات الاخري. - كذلك تم تقدير النشاط المضاد للاكسده للكاروتيندات المفصوله من قشور الطماطم باستخدام



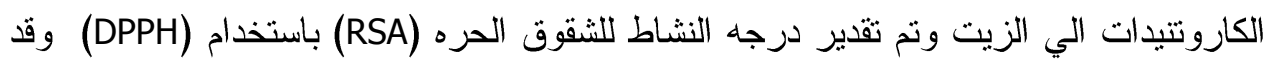

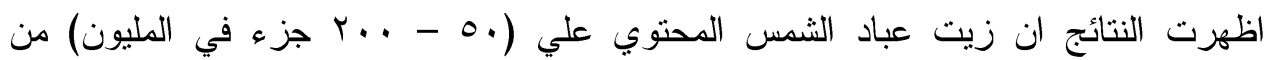

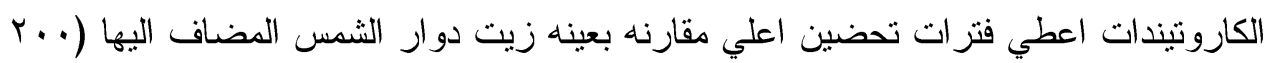

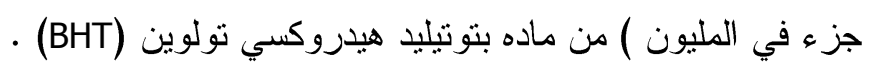

